\title{
EFFORT TO FULFILL FEMALE CONVICTS' RIGHTS TO HEALTH AND CLOTHING AT SIGLI CLASS IIB CORRECTIONAL FACILITY FOR WOMEN
}

\author{
Mustafa, Suhaimi, Darmawan \\ Master of Law Studies, Faculty of Law, Syiah Kuala Aceh University \\ Corresponding email: mustafamih74@gmail.com
}

Paper received on: 01-04-2021; Revised on: 04-05-2021; Approved to be published on: 05-05-2021;

DOI: http://dx.doi.org/10.30641/dejure.2021.V21.237-242

\begin{abstract}
Article 14 Paragraph (1) letter d of Law Number 12 Year 1995 concerning Corrections. The right to health services and the right to adequate clothing are often neglected and have not been fully implemented properly. The purpose of this research is to find out and explain the fulfilment of the rights to health and clothing of female convicts at the Sigli Class IIB Correctional Facility for Women. This research method is an empirical juridical method by using a descriptive analysis approach. The results of the study showed that the fulfilment of the rights to health and clothing has not been implemented optimally pursuant to what is mandated by law, and Article 14 Paragraph (2) of Government Regulation Number 32 Year 1999 concerning Terms and Procedures for the Implementation of the Rights of Correctional Inmates. To ensure optimal health services, at least one doctor must be provided. However, in this case it is not yet available at the Sigli Class IIB Correctional Facility for Women. One of the efforts made by the correctional facility is to collaborate with the local government to check the health of correctional inmates at least 1 (one) time in 1 (one) month and it is recorded in a health card. As for clothing need, it has been given partly to female convicts, but has not been given in full due to the lack of budget given to the Sigli Correctional Facility for Women. The responsibility of the state is to finance the fulfilment of the rights that have been regulated in the law, for example in the provision of health and clothing rights in a Correctional Facility, the facility shall have at least a doctor, nurses, clinics and medicines sufficient to support health facility in the Correctional Facility or Detention Center.
\end{abstract}

Keywords: fulfilment; health and clothing rights; female convicts

\section{INTRODUCTION}

The Sigli Class IIB Correctional Facility for Women building was built in 2006 and was functioned for the first time on March 1, 2015 with the appointment of a Caretaker named Muhktar, S.H. on May 21, 2015. From 2015 to 2020, there have been 3 (three) head changes in the Correctional Facility for Women. Currently, the Head of the Correctional Facility is Endang Sriwati, A.Md.IP., S.H., M.Si.

The Sigli Class IIB Correctional Facility for Women has a capacity of 110 people. Currently, the occupancy (per 31 December 2018) is 95 people, which decreased by $21 \%$ (to 74 people) in 2019 , and again increased to 101 convicts and detainees (per 31 December 2020) ${ }^{1}$. In addition to the Sigli Class IIB Correctional Facility for Women, female convicts are also existed and recorded in

http://smslap.ditjenpas.go.id/public/grl/detail/ monthly/upt/ca74c330-a75a-175a-a43f-303930313531 (Diakses 15 Maret 2021) every Correctional Facility and Detention Center spread across the Aceh region. The way to educate Correctional Inmates needs to be developed so that it becomes clear that the function of Correctional Facility has changed, from place for punishment to place for development ${ }^{2}$.

Currently, the world of work makes women free to interact with the public, makes women have more desires that make them vulnerable to environmental influences, so that most crimes that occur around are caused by economic factor and are really due to pressing circumstances. Some crimes are also caused by desire to get a higher economic position (luxury).

For women who are often outside the home and have associations from various circles and professions, the environmental or social factors influenced them to fulfill a lifestyle. To be able to adapt to the environment, women need a lot of material and they are lured to add additional

\footnotetext{
Irwan Petrus Panjaitan dan Pandapotan Simorangkir, Lembaga Pemasyarakatan Dalam Perspektif Sistem Peradilan Pidana (Jakarta: Pustaka Sinar Harapan, 1995).
} 
income in various ways that are justified in order to meet their needs.

Several criminal acts tend to be committed in order to meet the unlimited needs, especially those related to property or assets. The examples of these criminal acts are fraud, embezzlement, theft, corruption and other criminal acts. One of the reasons behind these crimes is the unlimited need which people want to fulfill in a short time by taking shortcuts, even by violating the law. The best way is to repent and educate to become a better society ${ }^{3}$.

Correctional Inmates can return and be accepted by the surrounding community like other human beings. Therefore, their rights must be considered and fulfilled, as regulated in the Correctional System according to Article 14 Paragraph (1) letter b and letter $d$ of the Law of Corrections. These rights include the right to receive treatment, both spiritually and physically, and to obtain health services. Even the right to obtain health services has been regulated in Article $28 \mathrm{~h}$ Paragraph (1) of the 1945 Constitution of the Republic of Indonesia which states: "Everyone has the right to live in physical and spiritual prosperity, to have a place to live, and to have a good and healthy living environment and have the right to obtain health services".

Furthermore, Article 7 Paragraph (1) letter b of Government Regulation Number 32 Year 1999 concerning Terms and Procedures for the Implementation of the Rights of Correctional Inmates stipulates that: "Every convict and correctional student has the right to receive physical care in the form of provision of clothing". Clothing, when viewed in terms of human needs, is classified as primary need. Based on this matter, the statement of the problem in this research is how the Fulfilment of the Rights to Health and Clothing of Female Convicts in the Human Rights Framework in the Sigli Class IIB Correctional Facility for Women is. The purpose of this research is to find out and explain the concept of human rights in the fulfilment of the rights to health and clothing of female convicts in the Sigli Class IIB Correctional Facility for Women.

Marlina, Hukum Penitensier, (Bandung: Refika Aditama, 2011).

\section{RESEARCH METHOD}

This paper used empirical juridical research method in order to find out the facts that occur in the field. The approach of this research is descriptive analysis, in which this research tried to explain in detailed, factual, systematic and accurate way about the facts, characteristics and relationships between the phenomena investigated ${ }^{4}$. 'Descriptive' means that this research aims to describe the Effort to Fulfill Female Convicts' Rights to Health and Clothing at Sigli Class IIB Correctional Facility for Women. The legal materials were reviewed by using library and field research techniques. The findings were analyzed by using qualitative analysis technique.

\section{DISCUSSION AND ANALYSIS}

\section{A. The Theory of Human Rights}

Article 1 Number 1 of Law Number 39 Year 1999 concerning Human Rights states, "Human Rights are a set of rights that are inherent in the nature and existence of humans as creatures of God Almighty and are His grace that must be respected, upheld, and protected by the state, law, the government, and everyone for the sake of honor and protection of human dignity". Human rights can differ from each other in terms of quantity, scope, and content in accordance with the culture and character of the people concerned .

Human rights must be treated the same as a justifiable claim, based on moral and legal grounds to have or obtain something or act in a certain way. However, the source of these rights is not from the state, not from society, not from religion, but the source of these rights comes from humans from the time they are in the womb. On that basis there is a claim to get their human rights from the state, which places the state as the bearer of responsibility. Therefore, convicts who are human beings as living creatures created by God Almighty and must be protected in obtaining their rights are the same as other humans who are not convict, but the state limits their rights to politics.

\footnotetext{
Moh Nazir, Metode Penelitian, (Jakarta: Ghalia Indonesia, 2003), hlm. 54-55

5 Hernadi Affandi, Persamaan Kedudukan di Depan Hukum dan Pemerintahan: Konsepsi dan Implementasi (Bandung: Mujahid Press, 2017), hlm. 85
} 
Legal protection of convicts can be interpreted as a legal protection effort for various freedoms and human rights of convicts (fundamental rights and freedoms of prisoners) as well as various interests relating to the welfare of convicts ${ }^{6}$.

Everyone's human rights are protected, whether in prison or not, so that a person who has been deprived of his liberty with a sentence, but is still sentenced to inhumane conditions in this sentence is an additional law. Therefore, someone who has been sentenced by the court and entered the Correctional Facility and then tortured or punished again is an act that is not humane in development. Therefore, the state shall facilitate and regulate how the rights of the convict are.

All human beings have the same basic rights and cannot be distinguished between one individual to another so that their dignity or honor must always be maintained and protected by every human being in the world. Furthermore, based on this matter, it is known that human rights are universal and their existence is not hindered by their place of effect and is not limited by space and time and cannot be separated and violated by anyone ${ }^{7}$.

\section{B. Theory of the State's Responsibility}

Talking about "the state's responsibility, the main essence is regarding the rights and obligations of the state concerning 2 (two) things, namely: (1) the state's responsibility for foreigners residing in its territory and their assets, and; (2) the state's responsibility in solving various domestic problems" 8 .

According to Evans Gareth and Sahnoum Mohamed", "the elements of the state's responsibility for protection include three specific responsibilities, namely:

6 Donny Michael, "Penerapan Hak-Hak Narapidana Di Lembaga Pemasyarakatan Klas IA Tanjung Gusta, Sumatera Utara Ditinjau Dari Perspektif Hak Asasi Manusia. Jurnal Penelitian Hukum DE JURE 17, Nomor 2 (2017): 249 - 263.

7 Widada Gunakarya, Hukum Hak Asasi Manusia, (Yogyakarta: Andi, 2017)

8 Mardianis, Penerapan Tanggung Jawab Negara Dalam Pengaturan Implementasi Undang-Undang Nomor 21 Tahun 2013 Atas Kerugian Pihak Ketiga, https://www. google.com/search?client=firefox-bd\&q=teori+tanggu ng+jawab+negara,diakses (Diakses 24 februari 2021).

9 Ibid. a. The responsibility to prevent, that is to address the root causes and direct causes of internal conflicts and other man-made crises that put the population at risk;

b. The responsibility to react, that is to respond to situations of human need that compel to take appropriate steps, which can include coercive measures such as sanctions, international determinations, and, in extreme cases, military intervention;

c. The responsibility to rebuild, that is to provide, especially after military intervention, full assistance with recovery, reconstruction and reconciliation, to address the causes of harm for which the intervention is designed to stop or prevent".

The description above shows that the responsibility of the state includes fulfilling human needs, including the provision of health and clothing for the Correctional Inmates. Moreover, the fulfillment of the right to health and clothing is a human right, so that the state is responsible for fulfilling these rights. Therefore, every individual, family and community have the right to obtain protection for their health, and the government is responsible and has the right to regulate and protect so that the community's right to healthy life is fulfilled" $"$.

"The responsibility of the state towards citizens according to the international law is that every state shall defend and protect its citizens, whether they are within their territory or outside their sovereign territory. The certainty of citizenship status determines that the state must provide protection to its citizens, including carrying out prosecutions so that the human rights of their citizens are respected" 11 .

1o Sri Isriawaty Fherial, Tanggung Jawab Negara dalam pemenuhan Hak Atas kesehatan masyarakat berdasarkan Undang-Undang Dasar Negara Republik Indonesia Tahun 1945, Jurnal Ilmu Hukuegal Opnion, Vol. 3 Nomor 2, (2015). hlm.4.

" Yuni Trining Vivid, Tanggung Jawab Negara Terhadap Warga Negara Indonesia Oleh Perwakilan Republik Indonesia Di luar Negeri Skripsi, Fakultas Hukum Universitas Airlangga, Surabaya,hlm.63,http:// repository. Unair.ac.id/47046/,(2013).(Diakses 24 Februari 2021). 


\section{The Fulfilment of the Rights to Health and Clothing of Female Convicts in the Human Rights Framework in the Sigli Class IIB Correctional Facility for Women}

Correctional Inmates are ordinary people just like other humans. However, because they have made a mistake, such as committing a crime, they have to spend their days in a closed place, namely Correctional Facility/Detention Center. However, in fulfilling their rights, the government must pay attention and provide the maximum possible service to protect the rights of the convicts. One of the rights of convicts is to obtain proper health services and food as regulated in Article 14 Paragraph (1) letter d of Law Number 12 Year 1995 concerning Corrections.

On the one hand, the recognition and affirmation of the right to health as part of human rights certainly emphasize the state's responsibility for fulfilling the right. In this case, the state has the responsibility to provide health facilities and public service facilities for all citizens ${ }^{12}$.

In measuring the realization of the state's responsibility for fulfilling the right to health, among others, it can be seen from the provision of health service facilities. In addition, there are other measures that can be used, namely: Life Expectancy, Infant Mortality Rate, Sickness Rate, Prevalence of Undernourished Toddlers, and other indicators relating to access to health care facilities such as the percentage of women who birth attendants were medical personnel, the percentage of the population who went to hospital, doctors/ clinics, Community Health Centers, and others, and the ratio of health workers per population ${ }^{13}$.

Health is an asset, because health is not an inheritance, health is a treasure. A healthy and decent life is a human right, everyone has the right to an adequate living standard for the health and well-being of himself and his family, including the right to food, clothing and health care as well as necessary social services and is entitled to guarantees for reaching old age or other conditions.

12 Hernadi Affandi, Implementasi Hak atas Kesehatan Menurut Undang-Undang Dasar 1945: antara Pengaturan dan Realisasi Tanggung Jawab Negara, Jurnal Hukum POSITUM Vol. 4, No. 1, Juni 2019, Hal 38

13 Badan Pusat Statistik, Indikator Kesejahteraan Rakyat Ketimpangan Pendidikan di Indonesia (Jakarta: BPS, 2016), hlm. 55.
Every detainee and convict must obtain optimal health services from health workers, both sick and healthy convicts ${ }^{14}$.

The right to the highest attainable standard of health is a human right recognized in the international human rights law. The International Covenant on Economic, Social and Cultural Rights, widely regarded as the central instrument of the protection of the right to health, recognizes "the right of everyone to the enjoyment of the highest attainable standard of physical and mental health." It is important to note that the Covenant provides equal consideration for both mental health, which is often overlooked, and physical health ${ }^{15}$.

In the implementation of health services, through the Decree of the Director General of Corrections Number: E.03.PP.02.10 Year 2003, the minimum standards of health services for convicts in Correctional Facility/Detention Center have been stipulated as follows:

a. Institutionally, the existing health services are still at a simple level, namely the services of doctors and clinics that are first aid.

b. Referrals for patients are carried out in a modest manner, depending on the conditions in each Correctional Facility.

c. The forms of promotive, preventive, curative, and rehabilitative services are carried out systematically.

Thus, it is clear that every convict has the rights as stated above which the government must fulfill these rights properly. So that if the convicts' rights are not fulfilled or not granted, it is clear that this is a violation of the laws and regulations by the state, especially since Indonesia is said to be a nation of laws. Therefore, it is very naive for a nation of laws to violate the law in reality.

The results of the research which was conducted at the Sigli Class IIB Correctional Facility for Women showed that the fulfillment of the right to health and clothing has not been carried out optimally in accordance with what is mandated by law and Article 14 Paragraph

\footnotetext{
${ }^{14}$ Nazaryadi, Pemenuhan Hak Kesehatan Narpidana di Lembaga Pemasyarakatan Narkotika Langsa, Syiah Kuala Law Journal, 1 (1) (2017). ISSN: 2546-1741

15 Mikho Ardinata, “Tanggung Jawab Negara Terhadap Jaminan Kesehatan Dalam Perspektif Hak Asasi Manusia," JURNAL HAM, 11 Nomor 2 (2020).
} 
(2) of Government Regulation No. 32 Year 1999 concerning Terms and Procedures for the Implementation of the Rights of Correctional Inmates, because at least one doctor and another health worker must be provided to ensure optimal health services. However, in this case they are not yet available at the Sigli Class IIB Correctional Facility for Women ${ }^{16}$. One of the actions taken by the Correctional Facility is to collaborate with the Health Office of Pidie District to check the health of some Correctional Inmates at least once a month and the result is written in a health record ${ }^{17}$. As for clothing need, it has been given to female convicts, but it has not been fully given because the number of convicts and detainees is increasing every day which is 132 people as of May 4, $2021^{18}$. According to the budget amount in the Budget Execution Document, the clothing shall be given to 68 inmates. However, the number of inmates has increased to 132 people. It is clear that the amount of budget given to the Sigli Correctional Facility for Women is not sufficient, due to the increasing number of the convicts.

The fulfillment of the right to a healthy life is a basic right that must be guaranteed, because health is part of the primary needs of every human being. Healthy condition of body and soul will enable every human being to carry out his activities and works. Health is also part of the need to live a prosperous life. This right is one of the basic rights in health services ${ }^{19}$.

The responsibility of the state is to finance the fulfillment of the rights that have been regulated in the law. For example, regarding the provision of health and clothing rights, a Correctional Facility shall at least have a doctor, nurses, clinics and medicines sufficient to support health facilities in the Correctional Facility or Detention Center.

According to Article 14 Paragraph (1) letter d of Law No. 12 Year 1995 concerning Corrections,

16 Shinta Aneta, Pegawai Lembaga Pemasyarakatan Perempuan Kls IIB Sigli, Wawancara Tanggal 4-052021.

${ }_{17}$ MOU (Nota Kesepahaman Kerjasama antara LPP Kelas IIB Sigli dengan Dinas Kesehatan Kab. Pidie Nomor : W1.PAS.27.PK.06.02 - 790)

18 http://smslap.ditjenpas.go.id/public/grl/detail/daily/ upt/ca74C330-a75a-175a-a43f-303930313531 di akses tanggal o4 Mei 2021

19 Mikho Ardinata, “Tanggung Jawab Negara Terhadap Jaminan Kesehatan Dalam Perspektif Hak Asasi Manusia," JURNAL HAM, 11 Nomor 2 (2020). convicts shall have the right to receive proper health services and food. The right to health services and the right to proper clothing are often neglected, in the sense that convicts do not always obtain these rights while they are in a Correctional Facility. One of the examples is the Sigli Class IIB Correctional Facility for Women, where the fulfillment of the right to proper health services and clothing has not been fully implemented well.

\section{CONCLUSION}

The fulfillment of the right to proper health and standard of living is recognized as a human right by human rights instruments. However, in this case, the fulfillment of the right to health and clothing in a Correctional Facility for Women has not been performed as expected, because there is still a lack of medical personnel. Clothing has not been fully allocated due to the lack of budget given to the Sigli Correctional Facility for Women. Thus, the state's responsibility to its citizens is one of the efforts in fulfilling the rights of Correctional Inmates.

\section{SUGGESTION}

Based on the description above, the researchers suggest the Ministry of Law and Human Rights, especially the Directorate General of Corrections, to pay more attention and see firsthand the condition of health and clothing of female convicts throughout Aceh and in particular the Sigli Class IIB Correctional Facility for Women, so that the fulfillment of health and clothing can be carried out properly in accordance with the mandate of Law Number 12 Year 1995 concerning Corrections.

\section{ACKNOWLEDGEMENT}

The researchers would like to thank the Head of the Corrections Division of the Regional Office of the Ministry of Law and Human Rights in Aceh, and in particular the Head of the Sigli Class IIB Correctional Facility for Women as informants in this research, the Correctional Facility officers who have provided the data and Correctional Inmates who have been willing to provide information in the field. The researchers would also like to thank the Thesis Supervisor and the directing lecturer who have contributed so that this research can be completed. 


\section{BIBLIOGRAPHY}

Hernadi Affandi, Persamaan Kedudukan di Depan Hukum dan Pemerintahan: Konsepsi dan Implementasi (Bandung: Mujahid Press, 2017).

Irwan Petrus Panjaitan dan Pandapotan Simorangkir, Lembaga Pemasyarakatan Dalam Perspektif Sistem Peradilan Pidana (Jakarta: Pustaka Sinar Harapan, 1995).

Marlina, Hukum Penitensier, (Bandung: Refika Aditama, 2011).

Moh Nazir, Metode Penelitian, (Jakarta: Ghalia Indonesia, 2003), hlm. 54-55

Widada Gunakarya, Hukum Hak Asasi Manusia, (Yogyakarta: Andi, 2017)

http://smslap.ditjenpas.go.id/public/grl/detail/ monthly/upt/ca 74c330-a75a-175aa43f-303930313531

Donny Michael, "Penerapan Hak-Hak Narapidana Di Lembaga Pemasyarakatan Klas IA Tanjung Gusta, Sumatera Utara Ditinjau Dari Perspektif Hak Asasi Manusia. Jurnal Penelitian Hukum DE JURE 17, Nomor 2 (2017): 249 - 263.

Hernadi Affandi, Implementasi Hak atas Kesehatan Menurut Undang-Undang Dasar 1945: antara Pengaturan dan Realisasi Tanggung Jawab Negara, Jurnal Hukum POSITUM Vol. 4, No. 1, Juni 2019, Hal 38

Mikho Ardinata, "Tanggung Jawab Negara Terhadap Jaminan Kesehatan Dalam Perspektif Hak Asasi Manusia," JURNAL HAM, 11 Nomor 2 (2020)

Nazaryadi, Pemenuhan Hak Kesehatan Narpidana di Lembaga Pemasyarakatan Narkotika Langsa, Syiah Kuala Law Journal, 1 (1) (2017). ISSN : 2546-1741

Mardianis, Penerapan Tanggung Jawab Negara Dalam Pengaturan Implementasi UndangUndang Nomor 21 Tahun 2013 Atas Kerugian Pihak Ketiga, https://www.google. com/search?client $=\mathrm{fi}$ fox-bd\&q=teori $+\tan$ ggung + jawab + negara, diakses (Diakses 24 februari 2021).
Badan Pusat Statistik, Indikator Kesejahteraan Rakyat Ketimpangan Pendidikan di Indonesia (Jakarta: BPS, 2016), hlm. 55.

Sri Isriawaty Fherial, Tanggung Jawab Negara dalam pemenuhan Hak Atas kesehatan masyarakat berdasarkan Undang-Undang Dasar Negara Republik Indonesia Tahun 1945, Jurnal Ilmu Hukuegal Opnion, Vol. 3 Nomor 2, (2015). hlm.4.

Yuni Trining Vivid, Tanggung Jawab Negara Terhadap Warga Negara Indonesia Oleh Perwakilan Republik Indonesia Di luar Negeri, Skripsi, Fakultas Hukum Universitas Airlangga, Surabaya, hlm.63,http:// repository. Unair.ac.id/47046/,(2013). (Diakses 24 Februari 2021).

Undang-Undang Dasar Negara Republik Indonesia Tahun 1945

Undang-Undang Nomor 12 Tahun 1995 tentang Pemasyarakatan

Undang-Undang Nomor 39 tahun 1999 tentang Hak Asasi Manusia.

Peraturan Pemerintah Nomor 32 Tahun 1999 tentang Syarat dan Tata Pelaksanaa Hak Warga Binaan Pemasyarakatan 